\title{
ENERGY AND EXERGY ANALYSIS OF SHAKARGANJ LIMITED JHANG THERMAL POWER PLANT
}

\author{
Tanveer UI Islam \\ Shift Engineer Mechanical, Shakarganj Ltd ,Jhang \\ Post Graduation in Mechanical Engineering student, Department of Mechanical Engineering, \\ University of Engineering and Technology Taxila
}

\begin{abstract}
Exergy analysis has sparked interest within the scientific community to require a more in-depth check up on the energy conversation devices. Exergy analysis gives entropy generation, irreversibility percentage exergy loss and second law efficiency. The exergy loss or irreversibility is the maximum at boiler. Thus to know about actual flow of exergy in the cycle thermodynamic analysis based on second law is desirable. In this report exergy analysis of operating condition of boiler has been carried out based on mass and exergy balance. The power plant boiler was simulated based on the measured operating data and the thermodynamic states of the plant components. . It has been found that maximum exergy destruction occurs due to combustion process. Exergy efficiency of boiler according to second law analysis and the exergy analysis of back pressure steam turbine is performed. It is found that at minimum flue gas outlet temperature second law efficiency is the maximum.
\end{abstract}

\section{INTRODUCTION}

\section{Steam Boilers}

Pressure 25 bar \& Temperature $350^{\circ} \mathrm{C}$

\begin{tabular}{|c|c|c|c|}
\hline Boiler \# & Make & MCR T/H & NCR T/H \\
\hline Boiler \# 1 & Babcock \& Wilcox & 40 & 35 \\
\hline Boiler \# 2 & Babcock \& Wilcox & 80 & 72 \\
\hline Boiler \# 3 & Yoshimine (IFL) & 80 & 72 \\
\hline Boiler \# 4 & Yoshimine (IFL) & 80 & 72 \\
\hline Boiler \# 5 & Yoshimine (Brother) & 80 & 80 \\
\hline
\end{tabular}

Power House Steam Turbines:

Pressure 25 bar \& Temperature $335^{\circ} \mathrm{C}$

\begin{tabular}{|c|l|l|c|c|}
\hline TG-Set \# & \multicolumn{1}{|c|}{ Make } & $\begin{array}{l}\text { Design Exhaust } \\
\text { Pressure \& Temperature }\end{array}$ & $\begin{array}{c}\text { Specific Steam } \\
\text { Consumption Kg/KWH }\end{array}$ & Capacity \\
\hline TG-Set - I & Qingdao China & $\begin{array}{l}\text { Back Pressure 1.5 bar, } \\
\text { Temp. 160 }{ }^{\circ} \mathrm{C}\end{array}$ & 10.5 & $6 \mathrm{MW}$ \\
\hline TG-Set - II & Qingdao China & $\begin{array}{l}\text { Back Pressure 3 bar, } \\
\text { Temp. } 185^{\circ} \mathrm{C}\end{array}$ & 12.6 & $6 \mathrm{MW}$ \\
\hline TG-Set - III & KKK Germany & $\begin{array}{l}\text { Back Pressure 1 bar, } \\
\text { Temp. } 160^{\circ} \mathrm{C}\end{array}$ & 14 & $2 \mathrm{MW}$ \\
\hline
\end{tabular}


Steam Turbine Energy \& Exergy Analysis:

Energy input is equal to product of mass of steam into turbine and its enthalpy at entry: Ėi $=\dot{m i} \times$ hi

Energy output is sum of heat extracted and heat exhausted.
E்o $=(\dot{m e x t} \mathrm{x}$ hext $)+($ mexh $\mathrm{x}$ hexh )

Work done is equal to the energy in steam at entry to turbine minus that at exit.

$W . D=\dot{E} i-\dot{E} o$

Energy Efficiency (1st Law efficiency) of Turbine :

$\eta \mathrm{I}=$ (Actual Power Develop by Turbine Shaft) / (Ėin -
Ėout)

Exergy Input : $\quad \Psi$ in $=\dot{m s}$ (hs -TOss)

2. Exergy Out: $\Psi_{\text {out }}=$ mext (hext-T0Sext) $+\dot{m}$ exh (hexh-TOSexh)

Exergy Destruction in Turbine: $\quad \Psi_{\text {des }}=\Psi$ in Yout - $\Psi$ power

\section{Inlet Conditions:}

\begin{tabular}{|c|c|c|c|r|}
\hline \multirow{4}{*}{ Impulse Steam } & \multirow{2}{*}{ Case\#1 } & mf in Steam & Pressure & Temperature \\
\cline { 2 - 5 } Turbine & 1 & $\mathrm{~kg} / \mathrm{s}$ & $\mathrm{Kpa}$ & $\mathrm{C}$ \\
\cline { 2 - 5 } & 2 & 3.69 & 2400.00 & 341.00 \\
\cline { 2 - 5 } TG-2 - 02 MW Back & 3 & 3.72 & 2400.00 & 346.00 \\
\cline { 2 - 5 } Pressure- 180 Kpa & 4 & 3.89 & 2400.00 & 342.00 \\
\cline { 2 - 5 } & 5 & 4.03 & 2400.00 & 341.00 \\
\cline { 2 - 5 } & 6 & 4.25 & 2400.00 & 346.00 \\
\cline { 2 - 5 } & 7 & 4.08 & 2400.00 & 346.00 \\
\cline { 2 - 5 } & 8 & 4.03 & 2400.00 & 346.00 \\
\hline
\end{tabular}

\begin{tabular}{|c|c|c|c|c|}
\hline Enthalpy & Entropy & To (38 C ) & Energy in & Exergy In \\
\hline $\mathrm{KJ} / \mathrm{kg}$ & $\mathrm{Kj} / \mathrm{kg} . \mathrm{k}$ & $\mathrm{C}$ & $\mathrm{KW}$ & $\mathrm{KW}$ \\
\hline 3108.58 & 6.83 & 311.00 & 11484.48 & 3636.33 \\
\hline 3120.02 & 6.85 & 311.00 & 11613.41 & 3684.78 \\
\hline 3110.87 & 6.83 & 311.00 & 11838.59 & 3750.01 \\
\hline 3108.58 & 6.83 & 311.00 & 12088.92 & 3827.72 \\
\hline 3120.02 & 6.85 & 311.00 & 12566.75 & 3987.26 \\
\hline 3120.02 & 6.85 & 311.00 & 13260.09 & 4207.25 \\
\hline 3120.02 & 6.85 & 311.00 & 12740.08 & 4042.26 \\
\hline 3122.30 & 6.85 & 311.00 & 12575.94 & 3991.84 \\
\hline
\end{tabular}

\section{Outlet Condition}

\begin{tabular}{|c|c|c|}
\hline mf-out & Pressure & Temperature \\
\hline $\mathrm{kg} / \mathrm{s}$ & Kpa & $\mathrm{C}$ \\
\hline 3.69 & 180.00 & 190.00 \\
\hline 3.72 & 180.00 & 174.00 \\
\hline 3.81 & 180.00 & 169.00 \\
\hline 3.89 & 180.00 & 168.00 \\
\hline 4.03 & 180.00 & 172.00 \\
\hline 4.25 & 180.00 & 171.00 \\
\hline 4.08 & 180.00 & 171.00 \\
\hline 4.03 & 180.00 & 172.00 \\
\hline
\end{tabular}




\begin{tabular}{|c|c|c|c|}
\hline Enthalpy & Entropy & Energy out & Exergy out \\
\hline $\mathrm{KJ} / \mathrm{kg}$ & Kj/kg.k & $\mathrm{KW}$ & $\mathrm{KW}$ \\
\hline 2851.65 & 7.52 & 10535.27 & 1900.30 \\
\hline 2819.42 & 7.44 & 10494.50 & 1876.60 \\
\hline 2809.31 & 7.42 & 10690.97 & 1907.05 \\
\hline 2807.28 & 7.42 & 10917.20 & 1946.48 \\
\hline 2815.38 & 7.44 & 11339.71 & 2025.72 \\
\hline 2813.35 & 7.43 & 11956.75 & 2134.90 \\
\hline 2813.35 & 7.43 & 11487.86 & 2051.18 \\
\hline 2815.38 & 7.44 & 11339.71 & 2025.72 \\
\hline
\end{tabular}

Exergy Analysis:

\begin{tabular}{|c|c|c|c|c|}
\hline Work Done & $\begin{array}{c}\text { Generator Power } \\
\text { Output }\end{array}$ & $\begin{array}{c}\text { 1st Law } \\
\text { Efficiency }\end{array}$ & $\begin{array}{c}\text { Exergy } \\
\text { Destruction }\end{array}$ & $\begin{array}{c}\text { 2nd Law } \\
\text { Efficiency }\end{array}$ \\
\hline KW & KW & $\%$ & KW & $\%$ \\
\hline 949.21 & 930.00 & 97.98 & 8634.96 & 16.80 \\
\hline 1118.91 & 960.00 & 85.80 & 8617.90 & 17.26 \\
\hline 1147.62 & 980.00 & 85.39 & 8783.92 & 17.32 \\
\hline 1171.72 & 990.00 & 84.49 & 8970.72 & 17.15 \\
\hline 1227.04 & 1020.00 & 83.13 & 9313.99 & 16.96 \\
\hline 1303.33 & 1080.00 & 82.86 & 9821.85 & 17.03 \\
\hline 1252.22 & 1100.00 & 87.84 & 9436.68 & 18.05 \\
\hline 1236.23 & 1050.00 & 84.94 & 9313.99 & 17.45 \\
\hline
\end{tabular}

\section{Boiler Energy and Exergy Analysis}

\section{Composition of Bagasse}

\begin{tabular}{|l|r|r|r|r|r|r|}
\hline \multicolumn{7}{|c|}{ Composition of bagasse. } \\
\hline & \multicolumn{1}{|l|}{ C\% $\%$} & \multicolumn{1}{l|}{ O2\% } & Ash \% & Moisture & \multicolumn{1}{|c|}{ Total \% } \\
\hline $\begin{array}{l}\text { Composition of dry bagasse i.e 0\% } \\
\text { moisture }\end{array}$ & 47 & 6.5 & 44 & 2.5 & 0 & 100 \\
\hline $\begin{array}{l}\text { Composition of wet Bagasse with } \\
\text { 50\% moisture }\end{array}$ & 23.5 & 3.25 & 22 & 1.25 & 50 & 100 \\
\hline $\begin{array}{l}\text { Composition of wet Bagasse with } \\
\text { 48\% moisture }\end{array}$ & 24.44 & 3.38 & 22.88 & 1.3 & 48 & 100 \\
\hline
\end{tabular}

Composition of
bagasse is,
$\mathrm{C} \quad=47 \%$
$\mathrm{H} 2 \quad=6.5 \%$
$\mathrm{O} 2 \quad=44 \%$
Ash $=2.5 \%$
Total $=100 \%$

\section{And Composition of wet}

Bagasse with $50 \%$ moisture

is,

C $\quad=0.47 \times 50=23.50 \%$

$\mathrm{H} 2=0.065 \times 50=3.25 \%$

$\mathrm{O} 2=0.44 \times 50=22 \%$

Ash $=0.025 \times 50=1.25 \%$
Moisture $=50 \%$.

Total $=100 \%$

\section{Bagasse combustion}

calculation:

$\mathrm{O} 2$ required for complete

combustion per $\mathrm{Kg}$ of

Bagasse

$\mathrm{C}+\mathrm{O} 2=\mathrm{CO} 212+32=$

$44(32 / 12) \times 0.2256=0.6016$

$\mathrm{Kg}$

$2 \mathrm{H} 2+\mathrm{O} 2=2 \mathrm{H} 2 \mathrm{O} 4+32=$

$36(32 / 4) \times 0.0312=0.2496$

Total $\mathrm{O} 2$ required. $=0.6016$

$+0.2496-0.2112=0.64$
$\mathrm{Kg} / \mathrm{Kg}$

Air required for Bagasse

Air Required for complete comb $=(100 / 23) \times 0.64=$

$2.783 \mathrm{Kg} / \mathrm{Kg}$

Excess air coefficient (RA) $=1.45$

Total Air Supply $=2.783 \times 1.45$ $=4.035 \mathrm{Kg} / \mathrm{Kg}$

Product of combustion per

$\mathrm{Kg}$ of Bagasse.

CO2. $(44 / 12) \times 0.2256=$

$0.8272 \mathrm{Kg}$ 
H2O. (36/4) $\times 0.0312=$

$0.2808+0.52=0.54$

O2. $4.035 \times 0.23-0.64=$

$0.28805 \mathrm{Kg}$

N2. $4.035 \times 0.77=$

$3.10695 \mathrm{Kg}$
$=$

$=$

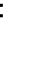

Gas Produced by $1 \mathrm{Kg}$ of Bagasse.

$0.8272+0.54+0.28805+3.106$ $95=4.7662 \mathrm{~kg} / \mathrm{kg}$

Composition of gas by weight $\mathrm{CO} 2=(0.8272 / 4.7662) \times 100=$ $17.4 \%$
$\mathrm{H} 2 \mathrm{O}=(0.54 / 4.7662) \times 100=$ $11.3 \%$

$\mathrm{O} 2=(0.28805 / 4.7662) \times 100=$ $6.0 \%$

$\mathrm{N} 2=(3.10695 / 4.7662) \times 100$ $=65.3 \%$

\begin{tabular}{|l|r|r|r|r|r|c|}
\hline \multicolumn{7}{|c|}{ O2 required for complete combustion per Kg of Bagasse } \\
\hline \multicolumn{1}{|c|}{$\begin{array}{c}\text { \% O2 Oasse Quality } \\
\text { For CO2 }\end{array}$} & $\begin{array}{c}\text { F O2 } \mathrm{F} 2 \mathrm{O} \\
\text { For in }\end{array}$ & $\begin{array}{c}\text { Required } \\
\text { O2 }(\mathrm{kg} / \mathrm{kg})\end{array}$ & $\begin{array}{c}\text { Air Req } \\
(\mathrm{kg} / \mathrm{kg})\end{array}$ & $\begin{array}{c}\text { Total Excess } \\
\text { Air }(\mathrm{kg} / \mathrm{kg})\end{array}$ \\
\hline $\begin{array}{l}\text { Total O2 Required for } \\
52 \% \text { Moisture Bagasse }\end{array}$ & 0.602 & 0.250 & 0.2112 & 0.640 & 2.783 & 4.0347826 \\
\hline
\end{tabular}

\begin{tabular}{|c|c|c|c|c|c|c|}
\hline \multicolumn{7}{|c|}{ Product of Combustion } \\
\hline & $\begin{array}{c}\text { Moisture } \\
\%\end{array}$ & $\mathrm{CO} 2$ & $\mathrm{H} 2 \mathrm{O}$ & $\mathrm{O} 2$ & $\mathrm{~N} 2$ & $\begin{array}{c}\text { Gas Produced } / \mathrm{kg} \\
\text { of Bagasse }\end{array}$ \\
\hline $52 \%$ Moisture Bagasse & 52 & 0.8272 & 0.8008 & 0.288 & 3.107 & 5.022782609 \\
\hline
\end{tabular}

\section{Boiler Efficiency Calculation:}

A simple method to measure the efficiency is to calculate the steam fuel ratio, i.e. is to measure the steam generated by unit mass of fuel. Steam fuel ratio, is directly proportional to boiler efficiency. Following ratios can be obtained for different fuels.

Coal $\quad 5.7$

Rice Husk $\quad 4.0$

Bagasse $\quad 2.2$

\section{Boiler Efficiency=}

This method is known as direct method which is based on simply that efficiency is equal to output divided by input. The other method is the indirect method of calculating boiler efficiency.

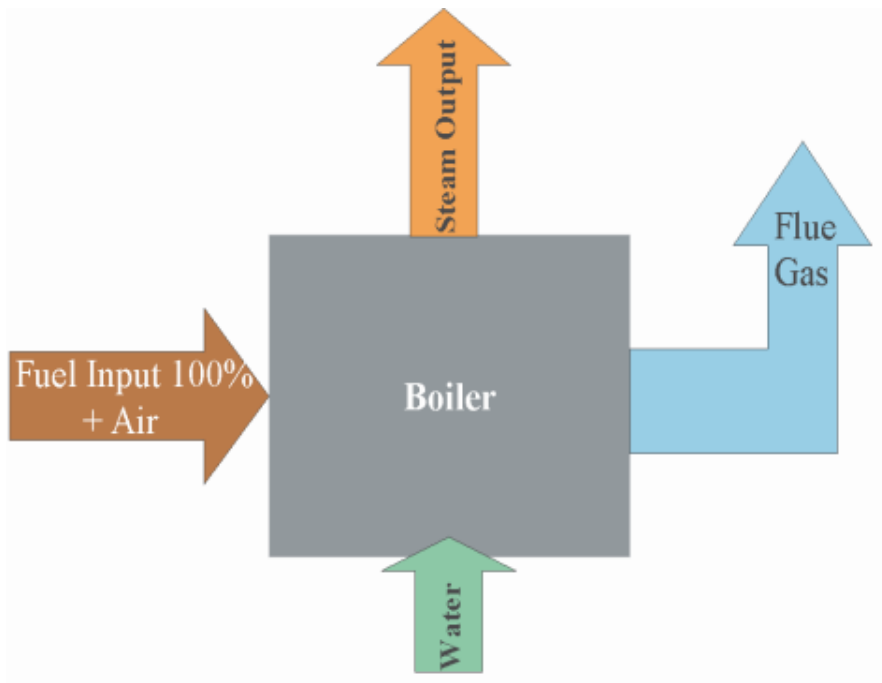

Efficiency $=$ Heat addition to Steam $\times 100$ Gross Heat in Fuel

To account the boiler losses a more better and precise formula for efficiency calculation is given below:

$\quad \eta=\quad \mathbf{x} 100$
Where,
$M v \stackrel{\text { Heat transfer to }}{ }$

steam per $\mathrm{kg}$ of bagasse burnt $\mathrm{NCV}=$ Net calorific value Also, 
$M v=(N \cdot C \cdot V-Q) \cdot \alpha \cdot \beta \cdot Y$

Where

$\mathrm{Q}=$ Sensible heat loss in flue gas

a. $\beta . y=$ Co-efficient of $x$-tics

of combustion efficiency

$\alpha=$ Co-efficient

representing heat loss due to

un-burnt solids.

$\beta=$ Co-efficient to account for heat losses by

radiation.

$y=$ Co-efficient of incomplete combustion.
For spreader stoker furnaces, its normal value $\alpha$ is taken as 0.975.

This value varies from 0.95 to 0.99 for more or less efficient lagging. Its value is taken as $\beta 0.97$.

Its value is taken as y 0.95

Whereas, $\mathrm{Q}=[(1-\mathrm{M}) \times(1.4 \mathrm{RA}-0.13)+$

Where,

$\mathrm{M} \quad=\%$ Moisture in Bagasse
RA =Ratio of excess Air $\mathrm{t}=$ Temperature of Flue gases

Here RA is ratio of excess air usually taken 1.45 for bagasse.

A better estimation of efficiency can directly be found by calculating the highest loss in Boiler which is sensible heat loss in flue gases in $\mathrm{Kcal} / \mathrm{Kg}$ of Bagasse.

The calorific value of bagasse in relationship to moisture and $\mathrm{Pol}$ is given below,

\begin{tabular}{|l|c|c|c|}
\hline Bagasse Quality & Net Calorific Value (kcal/kg) & Moisture & Pol \\
\hline $52 \%$ Moisture Bagasse with Pol 2.0 \% & 1704 & 52 & 2 \\
\hline $50 \%$ Moisture Bagasse with Pol 2.0 \% & 1801 & 50 & 2 \\
\hline $48 \%$ Moisture Bagasse with Pol 2.0\% & 1898 & 48 & 2 \\
\hline
\end{tabular}

\begin{tabular}{|c|c|}
\hline \multirow{2}{*}{ Flue Gas outlet temperature Tout ( C ) } & Loss of Sensible Heat Q (Kcal/kg of bagasse) burnt \\
\cline { 2 - 2 } & $52 \%$ Moisture Bagasse with Pol 2.0 \% \\
\cline { 2 - 2 } & NCV 1704 kcal $/ \mathrm{kg}$ \\
\hline 180 & 241.99 \\
\hline 190 & 255.44 \\
\hline 200 & 268.88 \\
\hline 210 & 282.32 \\
\hline 220 & 295.77 \\
\hline 230 & 309.21 \\
\hline 240 & 322.66 \\
\hline 250 & 336.10 \\
\hline 270 & 349.54 \\
\hline & 362.99 \\
\hline
\end{tabular}

After calculation of sensible loss, heat transfer to steam can easily be found by,

\begin{tabular}{|c|c|}
\hline \multirow{2}{*}{ Flue Gas outlet temperature Tout ( C ) } & Mv, Heat transfer to steam/ kg of Bagasse burnt \\
\cline { 2 - 2 } & $52 \%$ Moisture Bagasse with Pol 2.0\% \\
\cline { 2 - 2 } & NCV 1704 kcal/kg \\
\hline 180 & 1313.56 \\
\hline 190 & 1301.48 \\
\hline 200 & 1289.40 \\
\hline 210 & 1277.32 \\
\hline 220 & 1265.24 \\
\hline 230 & 1253.16 \\
\hline 240 & 1241.09 \\
\hline 250 & 1229.01 \\
\hline 260 & 1216.93 \\
\hline 270 & 1204.85 \\
\hline
\end{tabular}


Bagasse efficiency is calculated by: using the equation:

$$
\eta I=\quad x 100
$$

In indirect method the amount of different losses is worked out or measured and finally the summation of losses is subtracted from 100.

Both methods are equally good and recognized for calculating boiler efficiency. In second method losses are calculated, when every loss is known one can find that which loss is major contributor for efficiency loss and can take the corrective measure to reduce it. One cans decide which loss is less and can be ignored. On focusing the important one boiler efficiency can be improved.

\begin{tabular}{|c|c|}
\hline \multirow{3}{*}{ Flue Gas outlet temperature Tout ( C ) } & Boiler 2 ${ }^{\text {nd }}$ Law Efficiency \\
\cline { 2 - 2 } & 52\% Moisture Bagasse with Pol 2.0 \% \\
\cline { 2 - 2 } & NCV 1704 kcal/kg \\
\hline 180 & 77.09 \\
\hline 190 & 76.38 \\
\hline 200 & 75.67 \\
\hline 210 & 74.96 \\
\hline 220 & 74.25 \\
\hline 230 & 73.54 \\
\hline 240 & 72.83 \\
\hline 250 & 72.12 \\
\hline 260 & 71.42 \\
\hline 270 & 70.71 \\
\hline
\end{tabular}

\section{Results and Conclusion:}

A detailed mathematical model has been established to calculate the effect of below mentioned parameters on the efficiency of Bagasse fired boilers.

Bagasse Moisture Bagasse Pol

Flue Gas Temperature Feed water Temperature

Retrofitting is used to alter the above mentioned parameters which directly influence the boiler operating efficiency which is linked to fuel consumption. Thus by installing retrofits, we can optimize the boiler efficiency and can save tons of fuel.

Various retrofits are used for specific purpose like Bagasse Moisture Could be reduced by optimize milling and Bagasse dryer

Bagasse Pol

Could be reduced by optimize milling operation

Flue Gas Temperatur Could be reduced by utilizing the available heat by economizer, Air Preheater, Re-heater and Bagasse dryer
Feed water

TemperatureCould be increased by economizer

After detailed calculations the relationship of bagasse consumption for steam generation has been found as per below table. For constant steam generation rate at isobaric and isothermal steam generation, bagasse consumption is variable and fully dependent on following, Feed Water temperature Fuel heating value Flue gases outlet temperature

\begin{tabular}{|c|c|c|c|c|c|c|c|}
\hline \multicolumn{8}{|c|}{ At 350 C and 25 Bar-a Steam and 110 C Feed water Temperature } \\
\hline \multicolumn{10}{|c|}{$\begin{array}{c}52 \% \\
\mathrm{~m}(\mathrm{~s}) \\
\mathrm{Kg}\end{array}$} & $\begin{array}{c}\mathrm{h}(\mathrm{s}) \\
\mathrm{Kj} / \mathrm{kg}\end{array}$ & $\begin{array}{c}\mathrm{h}(\mathrm{w}) \\
\mathrm{kj} / \mathrm{kg}\end{array}$ & $\begin{array}{c}\mathrm{N} . \mathrm{C} . V \\
\mathrm{kj} / \mathrm{kg}\end{array}$ & $\begin{array}{c}\text { Flue Gas } \\
\text { Tout }(\mathrm{C})\end{array}$ & Efficiency \% & $\begin{array}{c}\text { Qty of Fuel } \\
(\mathrm{kg})\end{array}$ & $\begin{array}{c}\text { Steam/Bagasse } \\
\text { Ratio }(\mathrm{kg} / \mathrm{kg})\end{array}$ \\
\hline 80000 & 3127 & 463 & 7130 & 180 & 77.08681706 & 38775.24618 & 2.063171943 \\
\hline 80000 & 3127 & 463 & 7130 & 190 & 76.37795967 & 39135.11596 & 2.044199897 \\
\hline 80000 & 3127 & 463 & 7130 & 200 & 75.66910229 & 39501.72816 & 2.02522785 \\
\hline 80000 & 3127 & 463 & 7130 & 210 & 74.9602449 & 39875.27405 & 2.006255804 \\
\hline
\end{tabular}




\begin{tabular}{|l|l|l|l|l|l|l|l|}
\hline 80000 & 3127 & 463 & 7130 & 220 & 74.25138752 & 40255.95223 & 1.987283758 \\
\hline 80000 & 3127 & 463 & 7130 & 230 & 73.54253013 & 40643.96891 & 1.968311711 \\
\hline 80000 & 3127 & 463 & 7130 & 240 & 72.83367275 & 41039.53839 & 1.949339665 \\
\hline 80000 & 3127 & 463 & 7130 & 250 & 72.12481536 & 41442.88333 & 1.930367618 \\
\hline 80000 & 3127 & 463 & 7130 & 260 & 71.41595798 & 41854.23529 & 1.911395572 \\
\hline 80000 & 3127 & 463 & 7130 & 270 & 70.70710059 & 42273.83507 & 1.892423526 \\
\hline
\end{tabular}

\section{Bibliography}

\section{Books}

1) Cengel, a. yunus, Heat and Mass Transfer Fundamentals \& Applications, $5^{\text {th }}$ Edition, McGrawHill Education, New York, 2015

\section{Journals}

1) Mr.Priyank Dave, Mr. Fenil Desai, Mr. Hitesh Tailor, Energy Conservation in Bagasse Fired Boiler, International Journal on Recent and Innovation Trends in Computing and Communication ISSN: 2321-8169 Volume: 2 Issue: 9

2) A. R. Esmaeili Sany, M. H. Saidi, J. Neyestani, Experimental Prediction of Nusselt Number and Coolant Heat Transfer Coefficient in Compact Heat Exchanger Performed with $\varepsilon-N T U$ Method, The Journal of Engine Research/Vol. 18 / Spring 2010, Iran, March, 9

3) Dr. M K Chopra, Ramjee Singh Prajapati, Thermal performance analysis of cross-flow unmixedunmixed heat exchanger by the variation of inlet condition of hot fluid, International Refereed Journal of Engineering and Science (IRJES volume 3, India, January, 3

4) U.C. Upadhiaya, Bagasse as a fuel, Int. Sugar J., 1991, vol. 93, no. 1111, pp. 132-138

5) Luiz E.C. Maranhao, Bagasse drying, Paper presented for the ISSCT combined factory/energy workshop, 1994, pp. 1/105-1/117 